\title{
The Status of Women's Land Rights After Land Rights Registration and Certification Program in Wonago District, Ethiopia
}

\author{
Achamyeleh Gashu Adam (PhD) Tegegn Tadesse Abay (MSc) \\ Bahir Dar University, Institute of Land Administration, PoBox 913, Bahir Dar, Ethiopia
}

\begin{abstract}
Land is very critical asset for human life survival and the back bone for rural women livelihood. Unfortunately, in most developing countries like Ethiopia women were discriminated and marginalized from access and control of land for centuries through customary practices. With an effort to recognize women's land rights, the government of Ethiopia both at federal and regional state level is implementing large land right registration and certification programs since 2003.This study, therefore, is aimed to assess the effect of land certification in securing women's land rights by taking wonago district of SNNPR as a case study area. Survey research method was employed to generate both quantitative and qualitative data from the respondents selected by using both probability and non-probability sampling techniques. Finally the finding of this research revealed that the implementation of land certification program in the study area has been affecting rural women positively by advancing their land rights but still some women are challenged by unsolved landholding insecurity problems. The study recommends further that beside to land certification and registration programs, awareness creation on the equality of men and women should be given more emphasis so as to minimize biasness from the community and to ensure women's equal rights on land.
\end{abstract}

Keywords: Certification; Ethiopia; Land Rights; Land Tenure; Security Women

DOI: $10.7176 / \mathrm{JCSD} / 50-01$

Publication date:July $31^{\text {st }} 2019$

\section{Introduction}

In many developing countries, where most rural poor rely on subsistence agriculture for their survival, land remains a critical asset. Small-scale food production and the women involved in it are the backbone of rural livelihoods: women farmers produce more than half of all the food grown in the world and 60 to 80 percent of the food grown in most developing countries. Wives remain in rural households and take up the primary responsibility for managing family farms (FAO, 2010b).

Access to and control of property, whether customary, statutory, or religious provides economic entry for women to key markets as well as social access to non-market institutions such as household- and communitylevel governance structures, where they can contribute to decision making. Without land, such opportunities are difficult or impossible for women to attain since land provides them with a basic means for subsistence and market production (FAO, 2010b). Unfortunately, gender disparities in land access remain very high around the world, regardless of a region's level of development. Some women, individually or in groups, "own" land on which they produce food and goods for their families, products to sell, or rental income, although their ownership is not legally recognized. In these cases, they may or may control the decisions made about the use of the land, depending on how important their production and income is their spouses, households, or other legal owners. Others may own property through a joint title with a husband or another family member and again may or may not control land use decisions. If the tally of female land ownership in Africa, for example, is based on jointly or individually titled land, the percentage would be very low because levels of titled land ownership are very low, even for men (FAO, 2010a).

As described by Gospal (2001), both statutory and customary legal traditions lay the foundation for men's and women's property rights, and thus, legal reform can be a powerful tool for strengthening women's land rights. Legal reform can have potentially far- reaching effects, such as by eliminating discriminatory provisions in property rights law, and redefining the basis of property rights to give women the right to own property. Legal reform can also encompass reforms in marriage and inheritance laws. Finally, legal reform can include attempts to change tenure forms and rules. Many countries have passed statutory laws that aim to reform discriminatory customary practices.

Ethiopia provides an example where the legal framework has sought to protect the interests of women. The Federal land laws were changed in 1997 and 2005 (FRLAUP 1997; 2005). The 1997 law provided the basis for the land registration and certification and the Oromiya and SNNP regions issued regional laws in 2002 and 2003 with more detailed implementation rules and regulations (OR 2002; 2003; SNNPR 2003; 2004). Joint certification of husbands and wives was implemented in both these regions.

Among other equity and efficiency concerns, the land certification program in Ethiopia attempts to address 
gender bias concerns of the current land-tenure system. The program issues a non-alienable joint certificate to both spouses that confer equity and joint land ownership. The certificates include maps of the land and photos of both husband and wife. The perception of increased tenure security also extends to polygamous households. Both husband and wives in polygamous households in Southern Ethiopia perceived their tenure security to have increased, with later wives perceiving a greater increase in their tenure security, possibly due to their weaker initial position as compared to first wives. In addition, the inclusion of wives' names on land certificates enhances public expectation of an equitable division of land upon divorce or the death of a spouse (Holden and Tefera, 2008).

Gender-equitable land registration processes also reinforce awareness of reforms in family law. Kumar and Quisumbing (2012) found that awareness about the land registration process is positively correlated with the shift in perceptions toward equal division of land and livestock upon divorce. The other experience with Ethiopia's land registration program suggests that having women in local land administration committees encourages participation of female headed households in the land registration process and does not decrease male headed households' participation. Having female members in the land administration committees also increases attendance at meetings relating to the land registration (Kumar and Quisumbing, 2012).

The situations of women living in different areas of the regions and villages of rural Ethiopia appears to be critical when one consider into aspects of gender equality and land rights of them. In particular, the situation of rural women in the Southern Nations, Nationalities, and Peoples Region (SNNPR) of Ethiopia, especially of Gedeo Zone women's access to land or benefit they can draw from land is severely limited because of cultural believes of societies through gender based division. Most of things are controlled by husband and women have not equal chance to perform what they want to do. Women become or act as heads of households only if they have no husband. They can't equally participate in decision making process with their husband to manage and control economic resources at house hold level and with in community. Land acquisition by unmarried, divorced, widowed and women in polygamous marriages are affected by community customs and traditions. These inequalities in access to and control over the resources have made women more vulnerable to poverty than men for many centuries in this study area. The study therefore aims to examine the status of women's land right after the implementation of land registration and certification programs with a particular emphasis to see whether the certification program has improved rural women's land rights security and by minimizing the customary discriminatory provisions in land rights in the at the study area.

\section{Theoretical and Empirical Review on Women's Land Right and Land Certification 2.1 Natural Link between Women and Land}

Women like men are naturally linked to land and property in different ways. In most contexts they maintain different resource rights, endowments, roles, and opportunities. These relationships to land are also importantly mediated by other aspects of identity, such as socio-economic status, class, ethnicity, and age among others. In general, women are often primary producers on land and caretakers of property, especially on more marginal lands in more isolated areas. The feminization of farming has been propelled by an increase in the number of men migrating to urban centers in search of waged work, but also by rural-to-rural and international migration (Deere, 2005; Lastarria-Cornhiel, 2006). Wives remain in rural households and take up the primary responsibility for managing family farms. Gender inequality is evident in western, central, and northern Africa and some parts of Asia whereas women seem to have better access to land in eastern and southern Africa and in parts of Latin America, the Caribbean, and Eastern Europe (UN, 2010). Further, an international comparison of agricultural census data by the Food and Agriculture Organization (FAO) of the United Nations (2010a) shows that across the board, only 20 percent of landholders are women and women's low access to land prevails across countries with different social, cultural, and economic backgrounds.

Moreover, although women in most rural areas have access to land, very few own land or have control over it. This is common in rural areas of Africa, South Asia, Latin America and the Caribbean. For example, Mbote (2005) notes that male household heads in Africa are still the main controllers of land on the assumption that the rights are held in trust for all household members, while women are granted only the right to access or use land.

\subsection{Reasons to Secure Women's Land Rights}

Women may gain many personal benefits from tenure security. Having well recognized property rights may increase their confidence and social status (Datta, 2006). It may help to solidify and recognize the identities of women from ethnic minorities or indigenous groups, and establish for them a sense of belonging. Having direct and secure access to land may also provide women with important psychological security and the autonomy from husbands and other male relatives to pursue the livelihoods they value (Sánchez, 2006; Garikipati, 2009). It may lead to significant improvements in household bargaining power and decision-making authority (Allendorf, 2007; Doss, 2013).

As such, some research suggests that women with strong land rights are not only more actively involved in 
important household decisions, but are also more effectively positioned to avoid abusive partnerships, domestic violence, and exploitative household labor arrangements, and can better control sexual relations (Agarwal and Panda, 2007; Grabe, 2010; Bhattacharyya et al.,2011). However, property rights for women can be equally important for men, children, and the elderly, not to mention, on a broader canvas, the future of individual countries. Secure land rights and productive inputs for women can translate into significantly more efficient production on the land; the FAO (2011b) argues that if women had the same access as men to land, inputs, and productive services, they could produce $20-30 \%$ more food, enough to take 100-150 million people out of hunger .

\subsection{The Practice of Land certification in Ethiopia}

Holden and Bezu (2013) argue that the initial weak household tenure rights due to earlier tenure reforms and policies in Ethiopia may cause men and their families to perceive their land rights as weak and insecure before receipt of land certificates. Men may also, therefore, perceive benefits in receiving joint land certificates, although the certificates imply a re-allocation of power over land within households. On the other hand, if men and their kin family perceive enhanced land rights of women through joint certification as a threat to their land rights, they may react opportunistically and be willing to fight for their traditional decentralized property rights, leading to increased within-household tensions. Certification may thus lead to a new Nash bargaining equilibrium or a new non-cooperative solution within households (Lundberg and Pollak, 1993, cited in Hoden and Bezu, 2014). Such tensions could also lead to increased intra-household tension, violence, divorce, and disputes in the court system.

The finding of Woldetensaye (2007) revealed that women in male headed households have little say on what crops to grow, on the amount to be stocked for household consumption and on the amount to be sold. Women need to grow crops they prefer to use for household consumption but are not mostly accepted by husbands. Decision-making on land and land related matters are not usually made in women's interests. Women in male headed households exercise less decision-making power as compared to FHHs. Women's low participation in community activities and in community decision making. According to Holden et al. (2009) cited in Holden and Ghebru (2011) land productivity was found to be more than $40 \%$ higher on owner-operated plots with land certificates than on owner-operated plots without land certificates. This is consistent with recent findings by Ghebru and Holden (2015) that farms without a land use certificate, on aggregate, are less productive than those with formalized use rights. Certification programs that seek to reduce tenure insecurity and increase productivity may have greater effects on male-headed households than female headed households. Controlling for the possibility that certification has a different impact on male and female productivity shows that maleheaded households gain significantly and women gain only modestly (Bezabih and Holden, 2010).

Holden (2008) stated that land registration and certification is likely to have reduced the amount of border disputes, perhaps partly due to better demarcation of plot borders and because of the renewal of witnesses on the location of plot borders. Land certificates protect against encroachment by neighbors and this is positive indications of the usefulness of the registration process also for female-headed households. The land registration and certification has contributed to reduce the number of border disputes and inheritance disputes and to increase the incentives to plant trees. In addition to this, Holden and Ghebru (2011) found that land registration and certification lead to better plot border demarcation and a significant reduction in plot border disputes.

\section{Research Methods and Materials}

The status of women's land rights after the implementation of land registration and certification program is assessed by taking the cases from Wonago District. Wonago district is one of six districts found in Gedoe zone of South Nations and Nationalities and Peoples Region (SNNPR) in the southern part of Ethiopia. It has seventeen rural and four urban kebeles (villages) administrative units. Geographically, the district is found 6012'22"N-6021'00"N Latitude and 38011'15"E-38019'50"E Longitude and bordered with Bule district to the East, Oromia region to the West and North and Yirga Cheffe district to the South (see figure 1 below). 
Figure 1: Map of the study area

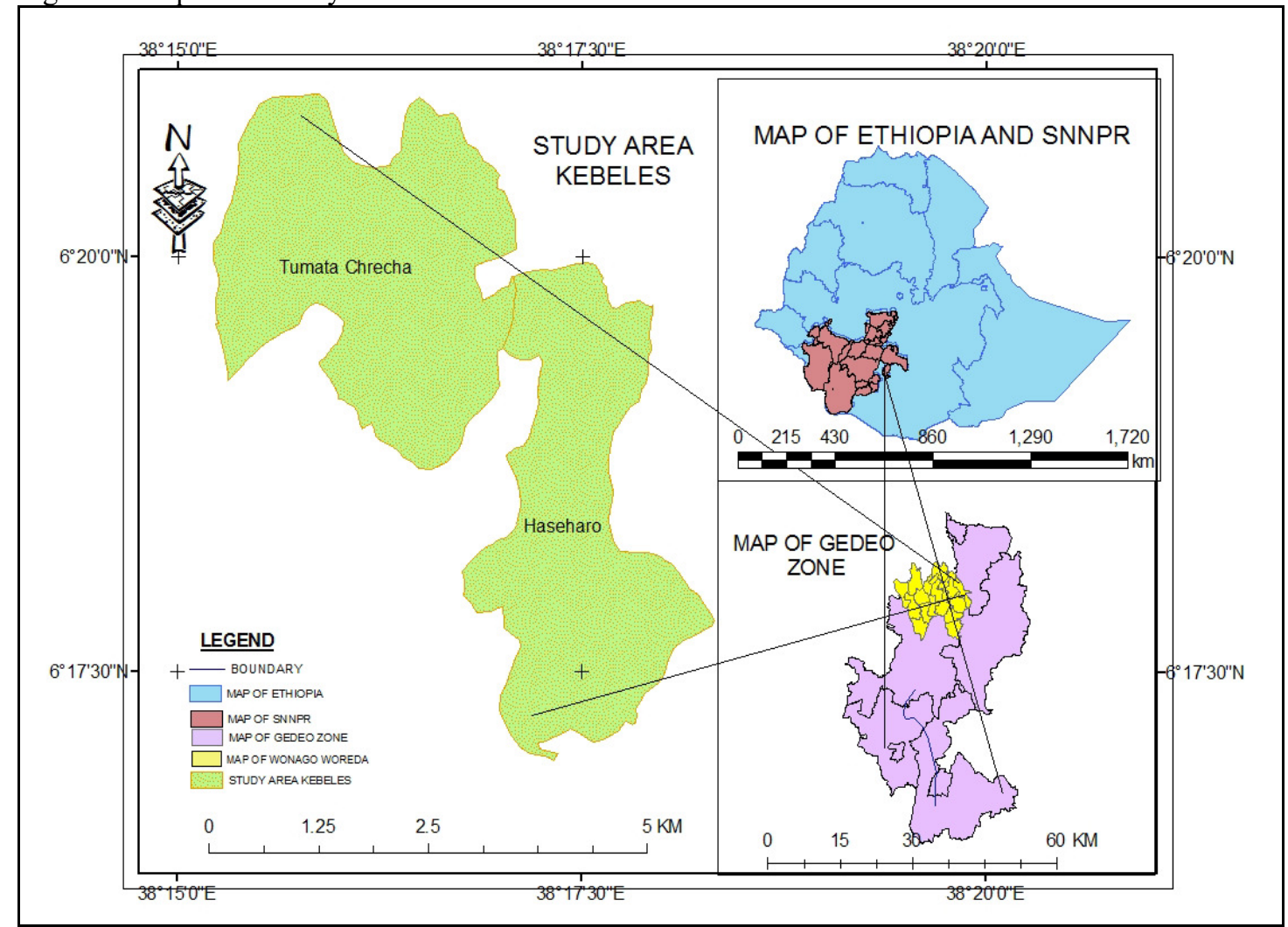

Source : Author Produced

Wonago District has a total population of 152,688 people, from which 76000 are male and 76,688 people are female, of which $90.2 \%$ live in rural area and $9.8 \%$ in urban area (WWDFED Office, 2009). The average population density of Wonago woreda is 1192 persons per square $\mathrm{km}$. This makes the woreda's highly densely populated area compared with the regional population density which is 164 people per square kilometer. Farmers' livelihood is mainly depends on agriculture (traditional agro forestry farming practices) which incorporates multiple tree species with different crops and animals. Coffee is the major cash crop of the study area and earns foreign currency to the country. False banana has a great role by feeding the society and conserving the environment.

In this study, a variety of quantitative and qualitative data were used and compared to provide more accurate findings. The study depends on both primary and secondary data sources. To get the required data from primary sources; questionnaire survey, interviews, focused group discussions and case studies were employed. Focus group discussions were conducted with different group of women such as women in male headed households, female headed households, women in polygamous households, widowed and divorced women in which on the issue of women land rights where before and after land certification has been conducted. Two women (one woman at each kebele) were taken as key informants who the land rights are guaranteed and empowered as well as outstanding examples for others were purposefully selected and the information's also gathered by using in-depth interviews with individual women. In addition to this, small focus group discussions were held with members of the two kebele's Land Administration Committee (LACs). Key informant interviews were also conducted with relevant woreda offices including the Office of the Land Administration and Use, Justice and women's and children affairs offices. Related literatures such as books, journals, web site, offices reports and documents were used as a secondary data source.

\subsection{Target Population and Sampling Design}

The study Woreda (Wonago) was selected purposefully from the total of six rural Woredas of Gedeo Zone because the existed problems which land accessing and benefit from it is severely limited to women, most of things are controlled by husbands and women cannot equally participate in decision making process with men, convenience of transportation, and access of essential data were the main selection criteria. From seventeen Kebeles of the Woreda's; two Kebeles (Hasse Harro and Tumata Chiracha) were also selected purposefully. The criteria that used for the selection were the existed women's land rights problems, distance/access of transportation from the administrative center of the Woreda, familiarity with local culture and language of the researcher and the issuance of land holding certification. In this study, all sampled population was selected by 
systematic random sampling technique. Book of record was used to select 192 certified women as sample respondents for questionnaire survey.

\section{Result and Discussion}

\subsection{Land Certification and Women's Land Rights at study area}

Land registration and certification programs with a purpose to improve land tenure security of landholders have been implemented in Ethiopia since 2003. According to District's land administration and case team (2008), from 30870 (Male 25931 and Female 4939), 30,060 or 97.37\% (Male 25153 and Female 4907) are issued primary level land holding certification. Out of these, 3202(2795 male and 407 female head) households are certified in the study areas of two kebeles. The data of survey respondents asserts that Out of 120 sampled monogamous women, 106(86.88\%) land parcel was measured and certified by the name of both husband and wives. 14(11.6\%) HHs land parcel was measured only by the name of husband, $18(75 \%)$ polygamous women got the land holding and use certificate with their husband and 6(25\%) polygamous women land measured and issued by only their husband's name.

This is shown that out of 144 married women, 124(86.1\%) land parcel was certified by the name of both husband and wives but the rest of 20(13.8) MHH women parcel of land measured only by their husband's name. 28 widowed and 20 divorced women have the certificate that issued by their own name. This result is consistent with the idea put on SNNPR land administration and use proclamation no.110/2007 Art.6/5 that "household head woman, she shall be given a land holding and use right certificate in her name." The study is found out the promising progress that most of rural women enabled to have land certificate specially widowed and divorced women at study area. But still a few of male headed women couldn't get land holding certificate.

\subsection{Rural women's perception of land tenure security before land certification}

This study has assessed women's perception and sense of security before rural land certification programs of the government. Almost $100 \%$ of survey respondents asserted that before land certification, there were no land rights at all and over controlled by husbands. At this time, women was totally discriminated from use and control rights of land, there was loss of land ownership rights in case of co farming, share cropping, renting, death of husband and divorce and frequent plot border dispute. Qualitative data of FGDs articulated that before land registration and certification, women haven't awareness of the rights of land at all. The people were expected "land rights are only the rights that had been given to men and exercised by themselves." There were huge burden dumped by women, they were simply considered as a servant even by their own husband's. All land rights of married women were depressed by their husbands, divorced women were simply leave away their life and didn't have guarantee, widowed women were also challenged by the family of her husband, young women did not inherit the land from their family and frequent bounder conflict was the main problems that manifested by rural women at study area before land registration and certification.

\subsection{Rural women's perception of land tenure security after land certification}

An assessment was also made to reveal rural women's perception of land tenure security after land certification. The survey shows that about $96.8 \%$ respondents' revealed that after the issuance of land certification, tenure security of rural women is changed. Have parcel registration and certification; women land rights were strengthen, enhanced women's bargaining capacity within their households and communities, incidence of land related disputes and border encroachment also reduced, enabling rural women to transfer and inherits the land rights and land productivity also enhanced. The FGDs participants expressed that now days women are free from the bondage that was attached them to not move and exercise land rights as a citizen. Now they all have land certificate, can participate in different discussion and heard their voice by men, the certificate also being guarantee them to borrow money from different institutions like Omo Micro Finance to perform different activities on their farm land. Even though the issuance of land certificate brought the changes mentioned above, some of rural women couldn't exercise equally these all rights with men and still the land rights problems are existed.

\subsection{Ways of land accessing for rural women}

Quantitative data of survey respondents of study area shown that $77.6 \%$ of total respondents accessed the land by marriage, $16.6 \%$ of respondents are accessed through inheritances and the rest of $5.7 \%$ are acquired by redistribution during the derg regime. The means of land acquisition with the relation of marital status is expressed on table six below that out of 144 married women, $88.19 \%$ of respondents accessed the land through marriage, $10.4 \%$ through inheritance and 1.3\% through land redistribution; out of 20 of divorced women, $50 \%$ are acquired through marriage, $30 \%$ through inheritance and the rest of $20 \%$ are through land redistribution; from 28 of total widowed women, $42.8 \%$ acquired land through marriage, $39.28 \%$ through inheritance and $17.8 \%$ of women are through land redistribution. The relationship of land acquisition ways with marital status 
shows that marriage which accounts $77.6 \%$ is the most dominant means of land accessing in study areas and few women can access the land through inheritance and land redistribution. Widowed women relatively have good progress by acquiring land through inheritance.

Table1. Relationship between land acquisition mechanism and marital status

\begin{tabular}{|c|c|c|c|c|c|c|c|c|c|}
\hline \multirow[t]{3}{*}{ No } & \multirow[t]{3}{*}{ Means of land accessing } & \multicolumn{6}{|c|}{ Marital status } & \multicolumn{2}{|c|}{ Total } \\
\hline & & \multicolumn{2}{|l|}{ Married } & \multicolumn{2}{|l|}{ Divorced } & \multicolumn{2}{|l|}{ widowed } & & \\
\hline & & frequency & $\%$ & frequency & $\%$ & frequency & $\%$ & frequency & $\%$ \\
\hline 1 & Marriage & 127 & 88.19 & 10 & 50 & 12 & 42.85 & 149 & 77.6 \\
\hline 2 & Inheritance & 15 & 10.41 & 6 & 30 & 11 & 39.28 & 32 & 16.6 \\
\hline 3 & Land redistribution & 2 & 1.38 & 4 & 20 & 5 & 17.85 & 11 & 5.72 \\
\hline & total & 144 & 100 & 20 & 100 & 28 & 100 & 192 & 100 \\
\hline
\end{tabular}

Source: Questionnaire survey (2017)

FGDs data asserts that marriage is the most land accessing way in their locality. This is because; most people expectation is that "land of women is on the hand of their husbands." Therefore, they will get the land after their marriage. On the other hand, they explained that after the land has been registered, some households have been given or transferred their parcel of land for their daughter's. For example: Ms. Bashura Dukale has 8 daughters and two sons and he had been equally shared or inherited the land for his all children. Ms. Geligelu Halichu's three young girls have been inherited the land equally with young boy's from their father. Bittu Abicho also accessed his land to four of his daughters. Aberash Gobena had been transferred the land right's for her two daughters.

The study has reflected that rural women have the rights and can acquire a land in different ways. From these, marriage is the most dominant land accessing means at the study areas and land holding right also guaranteed by land certificate and there are a hopeful beginning that land certification enables some rural women to acquire or inherit the land from or to their families at early stage and after their marriage of their life.

\subsection{Rural women land rights of use and control in study area}

In SNNPR rural land administration and use proclamation no. 110/2007 art. 5/2 stated that husband and wife have equal use right on their common land holdings. Art. 5/6 also notes that women house hold heads shall have full use right on their rights on their land holdings. Survey respondents' of quantitative data revealed that land registration and certification benefited rural women in different ways with their marital status accordingly. Out of total surveyed respondents, $68.2 \%$ respondents' can cultivate and produce what they want to produce on their land without restraint. Thus, agricultural productivity and food availability enhanced. $60.9 \%$ of respondent's cash income also increased and $77.08 \%$ of respondents can send their children to school and have a potential to pay for health service.

Out of total survey respondents $130(67.7 \%$ ) which means $61.66 \%$ of monogamous and $58.3 \%$ of polygamous respondent's of married women, $(85.7 \%)$ of widowed and $(90 \%)$ divorced respondents have the rights to use, control and make a decision on the yield and income of land and its resource which they have with their husbands as well as by their own selves. This result show that the implementation of land certification enables rural women to produce more and being benefited due to the enhancement of sense of ownership. But, the rights of control and use of land of married women is still not equally guaranteed with their husbands. But widowed and divorced women have better progress because land certificate have protect and enable them to produce more, to plan, cultivate, earn yield and benefit from land by own selves.

This study is found out that; land certificate has reduced the hesitation that was retard rural women to not actively participate on their farms and their confidence became increased to perform different activities. The positive impacts of land certificate bring changes on their livelihood. Even if there are progress that enable rural women being successful, the better achievements are recorded on divorced and widowed women relatively. This is because, after the decision is made on the issue of divorce, the parcel of land is divided based on the number of land parcel recorded on land holding and use certificate. After this process, the women can perform on the land what they want to do without restriction. The certificate also being guarantee for those of widowed women and the land rights of married women even guaranteed by this certificate. On the other hand, still there are restrictions that slow down some of married women to not fully and equally exercise, use and control of land rights with their husbands.

\subsection{Women participation in the decision making process}

Quantitative data of survey respondents' show that out of total survey respondent's $118(61.4 \%)$ have the rights to participate on decision making within their house hold. Out of these, $57.5 \%$ are monogamous, $45.8 \%$ polygamous, $78.57 \%$ widowed and $80 \%$ are divorced women. In other ways, $52.6 \%$ survey respondents $(50.8 \%$ of monogamous, $33.3 \%$ polygamous, $67.85 \%$ widowed and $65 \%$ of divorced women) are involved and have a 
chance to make decision within their community. The participation or representation of women on LACs was too less and only $4.68 \%$ respondents were agreed on the participation of women in LACs.

Qualitative data of FGDs revealed that after land certificate delivered to rural women, the things became changed. They have saying or can decide on different issue of their life. Their husbands also could discussed with them or ask them to plan and work together. Today's Women have a chance to participate and rise up any ideas by attending on different meetings within the community. But, some of male headed households or husbands are still challenged their wives by ignoring them to not freely made a decision and to not have a chance to participate in different areas of discussion. Lack of awareness also challenged some of widowed and divorced women to not have an exposure to participate in different area of decision making. This also revealed that unless and otherwise receipt of land certification supported by strong awareness creation work, it could not strengthen women by itself to involve and participate in land related issues.

The other problem of the study area is less involvement of women in kebele LACs. Woreda land administration and use case team expressed that out of 99 members of LACs at 17 woreda kebele's, only 7 women were being a member of LACs at five kebeles. The rest of twelve kebeles did not represented by women. Woreda's land administration expert Markos Ruffo explained that "there was no strong and well organized kebele LACs, and the involvement of women as a member was too less because the government was not pay attention to address this issue starting from structural set up of LACs. This research found out the beginning of women representation in LASc rather found and expressed by Qoricho(2011) that of the representation of women in LASc was completely absent in Sodo Zuria district.

This study is shown that land certification enabled and empowered rural women to involve and have a chance to make a decision on the different issues within households and their community. But, rural women have scored better result on decision making at household level rather their community in general. This is due to lack of awareness, bad social perception on attending women in different meetings and weak attention of concerned bodies to build up rural women understanding. The other thing which assessed by this study is that the participation and chance to make a decision by married women is less at household and community level. This is because, husbands are still taking a position of wives to make a decision and over control the resources. Women are not actively involved and participated in the member of kebele land administration and use committee for last twelve years. But, the bargaining power and participation of divorced, widowed and some of married women in different discussion is hopeful and enabled them to rise up and claim many ideas equally with men.

\subsection{Land certification and its Effect in solving land related Conflicts}

Land conflicts most of the time emanate from the unclear property right where the rights are not clearly registered and certified. To check this survey was conducted to see the level of conflict before certification. The questionnaire survey of the respondents revealed that $47.9 \%$ respondents were faced with land and land related disputes before land registration and certification. Out of those disputes, $55.43 \%$ are boundary dispute, $21.7 \%$ are resource use and control $15.2 \%$ are divorce, and $7.6 \%$ are inheritance disputes. Boundary dispute and resource use and control disputes were mainly dominant disputes in the study areas before the issuance of land. Data of survey respondents show that currently $51(26.5 \%)$ of survey respondents are faced with different land and land related disputes. Out of these, 21(41.1\%) respondents' faced with resource use and control dispute, $18(35.29 \%)$ respondent' faced with inheritance dispute, $7(13.72 \%)$ are faced with divorce dispute and the rest of $5(9.8 \%)$ respondent' are faced with boundary disputes.

The status of land conflict after certification has been also assessed. The data from questionnaire survey revealed that after the implementation of land certification, the degree of land disputes are decreed in general from $47.9 \%$ to $26.5 \%$ (it is reduced by $21.4 \%$ ). The disputes of boundary decreased from $55.43 \%$ to $9.8 \%$ and divorce disputes also decreased from $15.2 \%$ to $13.72 \%$ (see figure 2). But disputes of resource use and control increased from $21.7 \%$ to $41.1 \%$ and disputes of inheritance increased from $7.6 \%$ to $35.29 \%$. This study is reflects that the issuance of land is highly brought the radical change on boundary encroachment and the land of women became guaranteed from their neighbors and disputes of divorce decreased relatively as well. This is because, views of rural community became changed due to land certificate and fear of current decision that passed based on land certificate by different stakeholders when rural women land is being encroached. 


\section{Figure2 degree of land disputes in $\%$ before and after land certification at study area}

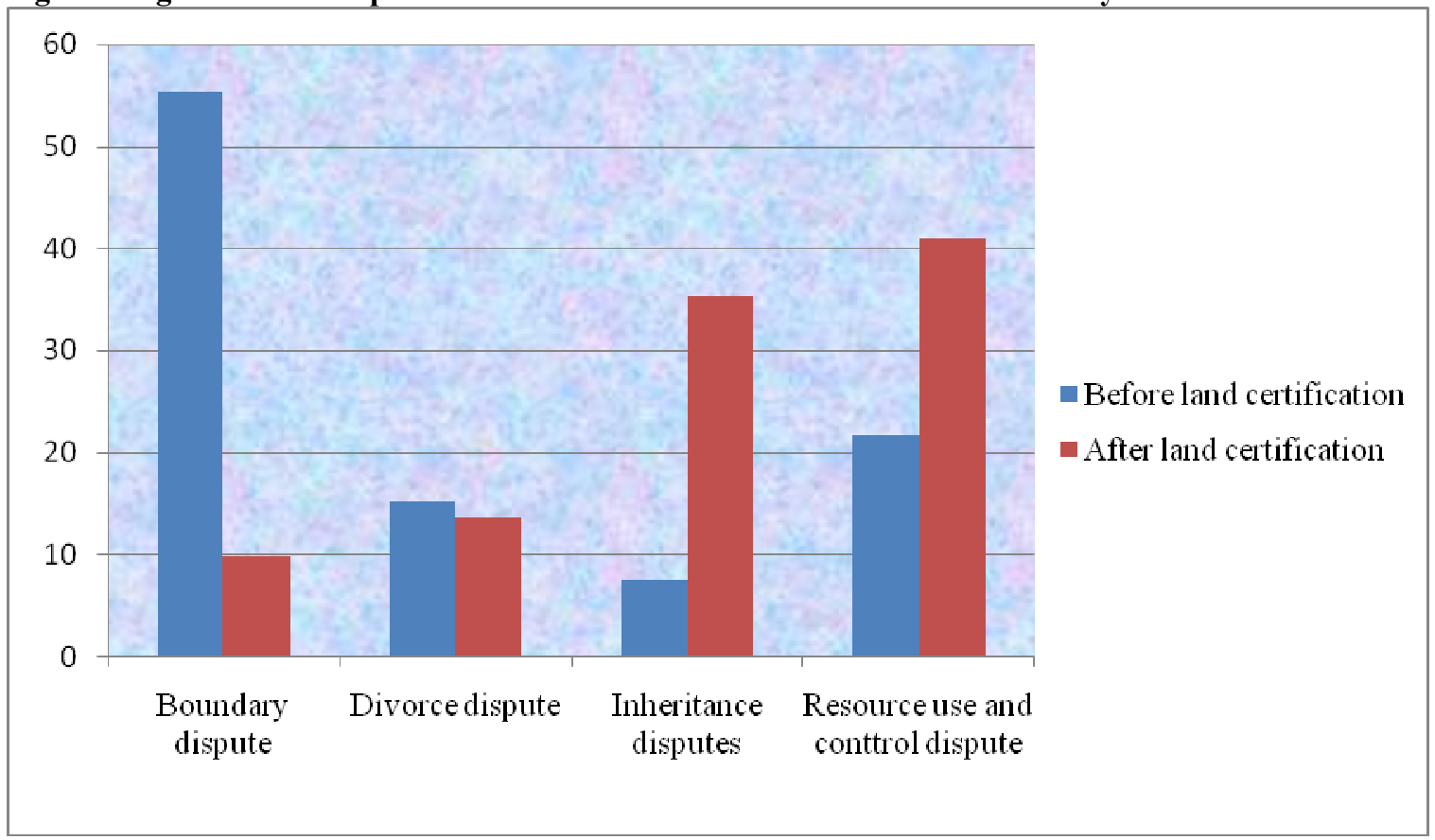

Source: survey respondent's data of Hasse Harro and Tumata Chiracha kebele (2017)

From key informants district court office president Legesse Gobena raised the idea that "now day's some of rural women appeal the case that related with holding rights of land and other properties. At this time they asked those women to bring land holding and use issuance certificate. This certificate helps them to make a decision easily. From the certificate, they checked either the holding or use right is both spouses or not. Having this evidence, they go to kebele administration and farm land in order to check up the reality on the ground. In 2016 sixteen women were appealed the case of divorce from five kebeles (Kalacha, Mokonissa, Hasse Harro, Dodoro and Jemijemo). Eight women cases have got a decision and the properties they have before divorce was being shared based on the decision of court office. The rest eight cases were on the process when this study was carried out.

This study is revealed that land certificate is facilitate the ways to rural women for secure their land rights by eliminating the hesitation and empowering them to argue for their land rights during inappropriate intervention of family as well as other community members. But lack of attention from concerned bodies and awareness problems of rural community, some of rural women still under the challenges at the time of resource use, control, divorce and death of their husbands at the study area.

\subsection{Effects of land certification on the enhancement of women's land productivity}

Land certification has the potential to enhance land productivity by women and men. About 131(68.2\%) of questionnaire survey revealed that their land productivity is enhanced after they have certified. This is because, sense of ownership of rural women is increased, due to this reason they can cultivate their land by using family labor and different imputes which enhance crop productivity, they spend more time on their farm land and the cost that was incurred to dispute resolution also reduced. Rural women are being confident and the hesitations also eliminated which were women feared for many centuries through their life. $31.8 \%$ respondents expressed that due to hesitation of some rural women; the farm land is not properly cultivated and managed. Thus, the land is not that much productive. The other reason is; even if women being secured their land rights, some of them are not managed the land in proper way to enhance its productivity.

\section{Conclusion}

Women were discriminated and marginalized from access and control of land for centuries through customary practices. But in many countries, the legal reform is used as a powerful tool for eliminating discriminatory provisions in property rights. Land certification is one of the appropriate reform and tool which the government has been implementing in most parts of the country including this study area with the purpose to improve the land tenure security of both women and men. Therefore, this study is primarily aimed to assess the status of women's land right after the implementation of certification programs.

In this study $96.8 \%$ of survey respondents have responded that after land certification, basically tenure security of rural women has been changed. The result of this study is shown that currently, even if marriage is 
the most dominant means of land accessing, the land holding right is guaranteed by land certification for both spouses. In addition to this, there are hopeful beginning that land certification enables some of rural women to acquire or inherit the land from their families at early stage and after their marriage. The implementation of land certification enables rural women to use, control and to make a decision on a yield and income of the land. $67.7 \%$ of married women $85.7 \%$ of widowed and $90 \%$ of divorced women have effectively exercised the rights of use and control on the property what they have. Unfortunately, some of married women still under the yoke of their husbands and cannot effectively use and control land and other resources due to awareness and bad social perception problems at the study area.

This study also revealed that the land certification enables rural women to involve and have a chance to make a decision on different issues within household and their community level. But rural women scored better result on decision making at $\mathrm{HH}$ level rather their community. The participation and a chance to make a decision by married women $(\mathrm{MHHH})$ is less at $\mathrm{HH}$ and community level. This is because some husbands are still taking position of wives to make a decision and ignoring and block them to not have chance to participate in different area of discussion. The participation or representation of women on LACs was too less.

The issuance of land certification brought the changes on land and land related disputes and became decreased from $47.9 \%$ to $26.5 \%$ after land certification. Therefore, land certificate facilitate the ways to rural women for secure their rights during the death of husbands, at the time of divorce and inappropriate treatment of land rights. This is because; when the disagreement is happened about inappropriate treatment of land between women and other people, women can appeal their cases with their land certificate to concerned bodies and the decision also made based on the data they have on the certificate. But due to lack of attention from concerned bodies and awareness problems of rural community, some of rural women still under the challenges especially at the time of resource use and control and inheritance at study area.

$68.2 \%$ of survey respondents revealed that their land productivity is enhanced after they have certified. This is due to sense of ownership of rural women has been increased thus; cultivate their land by using different inputs that enhance crop productivity. But, $31.8 \%$ of survey respondents revealed that due to the hesitation that existed by some women and improper management the land could not be productive. The governmental institutions were not well organized, did not due attention for the effectiveness of LACs. lack of governmental focus, instability and lack of well trained experts and weak coordination with rural community and lagging of decision are the main problems of concerned bodies and affecting the implementation of rural land policy at study area but giving attention and follow up to solve existed problems to rural women on woreda court office is hopeful beginning.

Future research should focus more greatly on the effective implementation of rural land policy and awareness creation work within the community at the study area. Empowering women to have effective participation on access, use and control of land is very important. Disputes of resource use, control and inheritance need special attention to address those of vulnerable rural women by assuring equitable resource distribution.

\section{References}

Agarwal, B. and Panda, P., 2007. "Toward Freedom from Domestic Violence: The Neglected Obvious." Journal of Human Development. 8(3), pp.359-388.

Allendorf, K., 2007. "Do Women's Land Rights Promote Empowerment and Child Health in Nepal?" World Development, 35(11), pp. 1975-1988.

Bezabih, M., and Holden, S., 2010. The Role of Land Certification in Reducing Gender Gaps in Productivity in Rural Ethiopia: Environment for Development. EFD Discussion Paper. Washington, DC: RFF Press.

Datta, N. 2006. "Joint Titling-A Win-win Policy? Gender and Property Rights in Urban Informal Settlements in Chandigarh, India. ” Feminist Economics, 12(1-2), pp. 271-298.

FAO, 2010a. Economic and Social Perspectives: Gender and Land Rights. Rome: FAO.

FAO, 2011b. FAO at Work 2010-2011: Women-Key to Food Security.

FRLAUP, 1997. Federal Rural Land Administration and Utilization Proclamation. Federal Democratic Republic of Ethiopia. 89/1997.

Gopal, G., 2001. Law and legal reform. In: Quisumbing AR, Meinzen-Dick R (eds) Empowering women to achieve food security, 2020 focus 6 brief 12. International Food Policy Research Institute, Washington, DC.

Holden, S., and Tefera, T., 2008a. From Being Property of Men to Becoming Equal Owners? Early Impact of Land Registration and Certification on Women in Southern Ethiopia. Nairobi: United Nations.

Holden, S., and Ghebru, H., 2011. Household Welfare Effects of Low-Cost Land Certification in Ethiopia. Centre for Land Tenure Studies Working Paper 03/11. Ås: Norwegian University of Life Sciences.

Israel, G.D., 1992. Sampling the Evidence of Extension Program Impact. Program Evaluation and Organizational Development, IFAS: University of Florida.

Kameri-Mbote, P. K., 2005). The Land Has Its Owners! Gender Issues in Land Tenure under Customary Law. 
Presented at the UNDP-International Land Coalition Workshop "Land Rights for African Development: From Knowledge to Action," Nairobi: Kenya, October31-November3

Kumar N, Quisumbing AR., 2012. Policy Reform Toward Gender Equality in Ethiopia: Little by Little the Egg Begins to Walk. IFPRI Discussion Paper 1226. International Food Policy Research Institute, Washington, DC.

Stein T. Holden and Sosina Bezu, 2014. Joint Land Certification, Gender Preferences, and Land Related Decisions: are Wives Getting More Involved? Centre for Land Tenure Studies/School of Economics and Business Norwegian University of Life Sciences, As, Norway.

UN, 2010. The World's Women 2010: Trends and Statistics. New York: UN Department of Economic and Social Affairs.URL.

Yonas Tafesse Qoricho, 2011. Women and Land Rights in Rural Ethiopia: The Case of Wolaita. University of Tromsø, Norway. 